\title{
E-learning for Part-Time Medical Studies
}

\author{
Wiesław Półjanowicz ${ }^{1}$, Robert Latosiewicz ${ }^{2}$, Barbara Kołodziejczak ${ }^{3}$, \\ Magdalena Roszak ${ }^{3}$
}

1 Department of Didactics and Modern Technologies in Education, University of Bialystok, Poland

2 Department of Rehabilitation and Physiotherapy, Medical University of Lublin, Poland

3 Department of Computer Science and Statistics, Poznan University of Medical Sciences, Poland

\begin{abstract}
Distance education undoubtedly has many advantages, such as individualization of the learning process, unified transmission of teaching materials, the opportunity to study at any place and any time, reduction of financial costs for commuting to classes or accommodation of participants, etc. Adequate working conditions on the e-learning portal must also be present, eg. well-prepared, substantive courses and good communication between the participants. Therefore, an important element in the process of conducting e-learning courses is to measure the increase of knowledge and satisfaction of participants with distance learning. It allows for fine-tuning the content of the course and for classes to be properly organized. This paper presents the results of teaching and assessment of satisfaction with e-learning courses in "Problems of multiculturalism in medicine", "Selected issues of visual rehabilitation" and "Ophthalmology and Ophthalmic Nursing", which were carried out experimentally at the Faculty of Health Sciences at the Medical University of Bialystok for nursing students for the 2010/2011 academic year. The study group consisted of 72 part-time students who learnt in e-learning mode and the control group of 87 students who learnt in the traditional way. The students' opinions about the teaching process and final exam scores were analyzed based on a specially prepared survey questionnaire. Organization of e-learning classes was rated positively by $90 \%$ of students. The average result on the final exams for all distance learning subjects was at the level of $82 \%$, while for classes taught in the traditional form it was $81 \%$. Based on these results, we conclude that distance learning is as effective as learning according to the traditional form in medical education studies.
\end{abstract}

\section{Introduction}

The dynamic development of e-learning in its various forms (eg. mlearning, blended learning, massive open online courses) helped to popularize this form of teaching. The use of a virtual learning environment (elearning portal) not only guarantees independency of place and time, but 
also allows one to access many groups of students (Meger, 2010). The fulfillment of these conditions is particularly important in the education of people working professionally who continue their education as part-time students.

Nowadays, distance learning is gaining more and more popularity among students of medical studies (Clarke, 2007; Hyla, 2012; Kołodziejczak et al., 2014; Półjanowicz et al., 2010, 2012, 2013; Półjanowicz, 2014; Smyrnova-Trybulska, 2009). The limitation of this form of teaching is the specificity of studies in the field of medicine, in which the practical classes must be conducted in the traditional form (eg. in hospitals, clinics or laboratories). However, most theoretical classes (lectures and seminars) can be successfully implemented in the form of distance learning. Verification of students' achievements can also be performed online using an e-learning portal, which contains tests of different types (eg. self-tests and exams) (Roszak et al., 2013). A well-prepared e-learning course enables the teacher to have comprehensive contact with students and to assess their progress in knowledge, activity, and involvement in the implementation of the tasks set (Roszak et al., in press). Distance learning is not, however, intended to replace traditional forms of education, but to supplement and expand it (Allan, 2007; Bramley, 2011; Smith et al., 2008; Wu et al., 2010).

Our previous research conducted at the Faculty of Health Sciences at the Medical University of Bialystok for the selected courses "Problems of

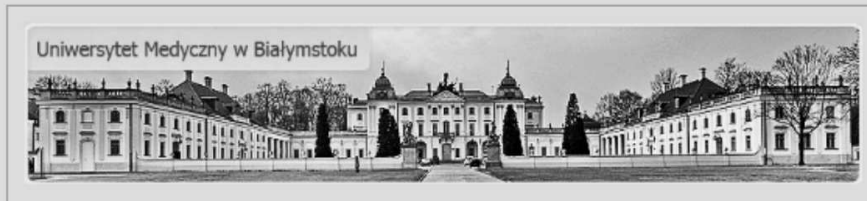

\section{Kategorie kursów}

Physiotherapy (Bachelor)

Therapeutic massage

Nursing (Master)

Selected issues in visual rehabilitation

Ophthalmology and ophthalmic nursing

Nursing (Master) - extramural studies

The problems of multiculturalism in medicine

Selected issues in visual rehabilitation

Ophthalmology and ophthalmic nursing

Nursing (Bachelor)

Obstetrics, gynecology and gynecological and obstetric nursing

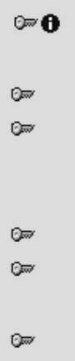

Figure 1. Main window of e-learning platform for the Medical University of Bialystok 
multiculturalism in medicine" and "Selected issues in visual rehabilitation" among full-time students (Figure 1) confirmed the fact that the effectiveness of teaching in the traditional and distance learning forms were comparable. Satisfaction of students with classes held in both forms was at the level of 85\% (Półjanowicz et al., 2013, 2014; Półjanowicz, 2014).

The aim of the present study was to evaluate and compare the effectiveness of teaching and satisfaction with the activities carried out with the e-learning portal by a group of part-time students of the Faculty of Health Sciences of the Medical University of Bialystok (Poland). In the analysis, we included the effectiveness of education, the level of student satisfaction with the course, and the interest of students in distance learning.

\section{Materials and Methods}

The research protocol was approved by the Bioethics Committee of the Medical University of Bialystok (Decision No. R-I-002/338/2009).

The study was conducted among 159 part-time students studying to obtain a master's degree in the field of nursing at the Medical University of Bialystok in the 2010/2011 academic year. Three subjects were experimentally taught using the blended learning method (b-learning): "Problems of multiculturalism in medicine", "Selected issues of visual rehabilitation" and "Ophthalmology and Ophthalmic Nursing". Lectures and seminars were conducted using the on-line system, but the exercises were carried out using the traditional method only. The content of courses taught according to the traditional way of teaching consisted of multimedia presentations (usually PowerPoint presentations), images and videos. Materials on the elearning platform were in the form of similar multimedia presentations, images, and videos. Additionally, there were quizzes, which assessed the students' knowledge. Students who participated in the e-learning courses had free and unlimited access to the educational portal of the Medical University of Bialystok (Figure 2), eg. the Moodle portal (Piskurich, 2003; Rice, 2010) (http://elearnig-umb.pl). The final exams of above mentioned subjects were held in the traditional form due to terms specified in the Regulations of Studies at the Medical University of Bialystok.

Within each subject, students were offered to freely choose to participate in the e-learning group or the group studying traditionally. There were a total of 72 people in e-learning groups. The rest of the students (87 people) had lectures and seminars in the traditional way in the halls of the University. 


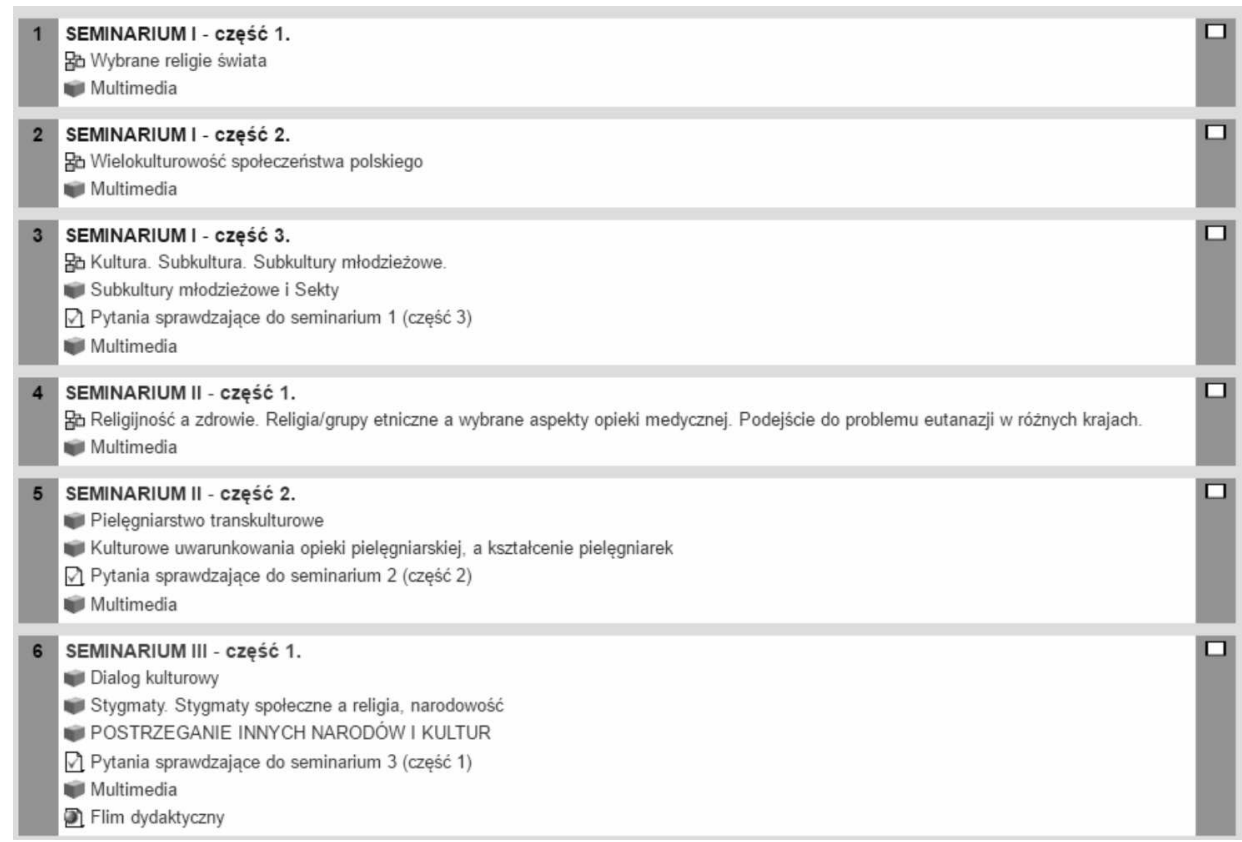

Figure 2. The main window of the course "Problems of multiculturalism in medicine"

In order to assess students' satisfaction with the classes in each subject for each of the surveyed groups, the responses of students to the following survey questions were analyzed:

1. Did the introduction of distance learning change the way you studied the specific subject?

2. Did e-learning have a positive impact on you?

3. Was the introduction of distance learning helpful in better understanding of the content of this subject?

4. Has the introduction of distance learning contributed to increasing the sustainability of your knowledge from this course?

5. Has the introduction of distance learning helped you to prepare to pass this part of the material of the subject?

6. Do you think that the standards set for passing exams were difficult?

7. What was the most valuable in this form of learning?

8. What was the most burdensome in this form of learning?

9. What should be changed in such a system of learning in the future?

10. What would you leave unchanged in this form of distance learning?

11. What should be improved?

12. Would you use this form of education, if possible, in the future? 
13. What is the impact of e-learning on the image of your university? Survey results were analyzed statistically using the Mann-Whitney $\mathrm{U}$ test. Calculations were carried out at statistical significance $\mathrm{p}<0.05$ in IBM SPSS Statistics 23 (IBM Corp. USA).

\section{Results and Discussion}

The vast majority of students in both groups were women $-90 \%$ in the e-learning group and $95 \%$ in the traditional group. All the people from the e-learning group had permanent access to the Internet. In contrast, among the 87 people from the traditional group, 9 persons (10\%) did not have regular access to the Internet. Daily use of the Internet was declared by more than $68 \%$ of students in both groups. Eighty-three percent of the respondents used Internet for web browsing. The surveyed students selfevaluated their computer skills and Internet use to be "well" and "very well" (Table 1). Differences between analyzed variables were not statistically significant $(\mathrm{p}>0.05)$.

Table 1. Subjective assessment of the ability to use a computer and the Internet in the surveyed groups of students

\begin{tabular}{|l|c|c|c|c|}
\hline \multirow{2}{*}{} & \multicolumn{3}{|c|}{ e-learning method $(\mathrm{n}=72)$} & \multicolumn{2}{c|}{ traditional method $(\mathrm{n}=87)$} \\
\cline { 2 - 5 } & No of persons & $\%$ & No of persons & $\%$ \\
\hline \multicolumn{3}{|c|}{ How do you rate your ability to use computers and the Internet? } \\
\hline poorly & 0 & $0 \%$ & 7 & $8 \%$ \\
\hline sufficiently & 5 & $7 \%$ & 14 & $16 \%$ \\
\hline rather good & 12 & $17 \%$ & 18 & $21 \%$ \\
\hline good & 25 & $35 \%$ & 22 & $25 \%$ \\
\hline very good & 30 & $42 \%$ & 26 & $30 \%$ \\
\hline
\end{tabular}

Analysis of responses to the questions in the survey clearly showed that people who were studying in the distance learning form very much appreciated this form of education (Table 2). All of the respondents assessed e-learning as a positive action. Eighty-five percent of the surveyed students declared that e-learning changed the way they learned the presented subjects (average of "yes" and "definitely yes" answers from the three subjects). Eighty-eight percent of students indicated that distance learning was helpful in better understanding the course content. For $76 \%$ of students, introduc- 
Wiesław Pótjanowicz et al.

Table 2. Students' satisfaction with e-learning classes for each subsequent course $(\mathrm{n}=72 ;$ numbers of presented questions are related to questions in the survey)

\begin{tabular}{|c|c|c|c|c|c|c|}
\hline & \multicolumn{2}{|c|}{$\begin{array}{c}\text { Problems of } \\
\text { multiculturalism } \\
\text { in medicine } \\
(\mathrm{n}=29)\end{array}$} & \multicolumn{2}{|c|}{$\begin{array}{l}\text { Selected issues of } \\
\text { rehabilitation of } \\
\text { vision organ } \\
(\mathrm{n}=19)\end{array}$} & \multicolumn{2}{|c|}{$\begin{array}{c}\text { Ophthalmology and } \\
\text { ophthalmological } \\
\text { nursing } \\
(\mathrm{n}=24)\end{array}$} \\
\hline \multicolumn{7}{|c|}{$\begin{array}{l}\text { 1. Did the introduction of distance learning change the way you studied } \\
\text { the specific subject? }\end{array}$} \\
\hline definitely no & 0 & $0 \%$ & 0 & $0 \%$ & 0 & $0 \%$ \\
\hline no & 1 & $3 \%$ & 0 & $0 \%$ & 0 & $0 \%$ \\
\hline slightly & 4 & $14 \%$ & 3 & $16 \%$ & 3 & $13 \%$ \\
\hline yes & 16 & $55 \%$ & 13 & $68 \%$ & 18 & $75 \%$ \\
\hline definitely yes & 8 & $28 \%$ & 3 & $16 \%$ & 3 & $13 \%$ \\
\hline \multicolumn{7}{|c|}{ 2. Did e-learning have a positive impact on you? } \\
\hline yes & 29 & $100 \%$ & 19 & $100 \%$ & 24 & $100 \%$ \\
\hline no & 0 & $0 \%$ & 0 & $0 \%$ & 0 & $0 \%$ \\
\hline \multicolumn{7}{|c|}{$\begin{array}{l}\text { 3. Was the introduction of distance learning helpful in better understanding of } \\
\text { the content of this subject? }\end{array}$} \\
\hline definitely no & 0 & $0 \%$ & 0 & $0 \%$ & 0 & $0 \%$ \\
\hline no & 0 & $0 \%$ & 0 & $0 \%$ & 1 & $4 \%$ \\
\hline slightly & 5 & $17 \%$ & 1 & $5 \%$ & 2 & $8 \%$ \\
\hline yes & 17 & $59 \%$ & 15 & $79 \%$ & 13 & $54 \%$ \\
\hline definitely yes & 7 & $24 \%$ & 3 & $16 \%$ & 8 & $33 \%$ \\
\hline \multicolumn{7}{|c|}{$\begin{array}{l}\text { 4. Has the introduction of distance learning contributed to increasing the sustainability } \\
\text { of your knowledge from this course? }\end{array}$} \\
\hline definitely no & 0 & $0 \%$ & 0 & $0 \%$ & 0 & $0 \%$ \\
\hline no & 1 & $3 \%$ & 1 & $5 \%$ & 0 & $0 \%$ \\
\hline slightly & 4 & $14 \%$ & 4 & $21 \%$ & 7 & $29 \%$ \\
\hline yes & 17 & $59 \%$ & 11 & $58 \%$ & 12 & $50 \%$ \\
\hline definitely yes & 7 & $24 \%$ & 3 & $16 \%$ & 5 & $21 \%$ \\
\hline
\end{tabular}




\begin{tabular}{|c|c|c|c|c|c|c|}
\hline & \multicolumn{2}{|c|}{$\begin{array}{l}\text { Problems of } \\
\text { multiculturalism } \\
\text { in medicine } \\
(\mathrm{n}=29)\end{array}$} & \multicolumn{2}{|c|}{$\begin{array}{l}\text { Selected issues of } \\
\text { rehabilitation of } \\
\text { vision organ } \\
(\mathrm{n}=19)\end{array}$} & \multicolumn{2}{|c|}{$\begin{array}{c}\text { Ophthalmology and } \\
\text { ophthalmological } \\
\text { nursing } \\
(\mathrm{n}=24)\end{array}$} \\
\hline \multicolumn{7}{|c|}{$\begin{array}{l}\text { 5. Has the introduction of distance learning helped you to prepare to pass this part of } \\
\text { the material of the subject? }\end{array}$} \\
\hline definitely no & 0 & $0 \%$ & 0 & $0 \%$ & 0 & $0 \%$ \\
\hline no & 0 & $0 \%$ & 1 & $5 \%$ & 0 & $0 \%$ \\
\hline slightly & 1 & $3 \%$ & 0 & $0 \%$ & 2 & $8 \%$ \\
\hline yes & 18 & $62 \%$ & 10 & $53 \%$ & 12 & $50 \%$ \\
\hline definitely yes & 10 & $34 \%$ & 8 & $42 \%$ & 10 & $42 \%$ \\
\hline \multicolumn{7}{|c|}{ 6. Do you think that the standards set for passing exams were difficult? } \\
\hline no & 27 & $93 \%$ & 16 & $84 \%$ & 20 & $83 \%$ \\
\hline yes & 2 & $7 \%$ & 3 & $16 \%$ & 4 & $17 \%$ \\
\hline \multicolumn{7}{|c|}{ 12. Would you use this form of education, if possible, in the future? } \\
\hline yes & 29 & $100 \%$ & 18 & $95 \%$ & 22 & $92 \%$ \\
\hline no & 0 & $0 \%$ & 1 & $5 \%$ & 2 & $8 \%$ \\
\hline \multicolumn{7}{|c|}{ 13. What is the impact of e-learning on the image of your University? } \\
\hline definitely negative & 0 & $0 \%$ & 0 & $0 \%$ & 0 & $0 \%$ \\
\hline negative & 0 & $0 \%$ & 0 & $0 \%$ & 0 & $0 \%$ \\
\hline does not affect/I don't know & 1 & $3 \%$ & 2 & $11 \%$ & 3 & $13 \%$ \\
\hline positive & 8 & $28 \%$ & 7 & $37 \%$ & 7 & $29 \%$ \\
\hline definitely positive & 20 & $69 \%$ & 10 & $53 \%$ & 14 & $58 \%$ \\
\hline
\end{tabular}

tion of this type of education has contributed to increasing sustainability of knowledge. Ninety-four percent of the students positively answered the question concerning assistance in preparation of course completion. Eighty-eight percent of surveyed students had no difficulties in meeting the standards set in those particular courses. Ninety-six percent of students indicated that they could benefit from e-learning in the future. The impact of e-learning on the image of the Medical University of Bialystok was rated to be positive or very positive by $91 \%$ of students.

Screenshots of the e-learning platform confirm students' satisfaction with classes conducted online (Figures 3, 4, 5).

The majority of students responded to the question: "What was the most valuable in this form of learning?" as: the ability to access materials at 
Wiesław Pótjanowicz et al.

\begin{tabular}{|c|c|c|c|c|c|c|c|}
\hline \multicolumn{8}{|c|}{ Czy wprowadzenie elementów zdalnego nauczania zmieniło sposób uczenia się przez Panią/Pana tego przedmiotu ? } \\
\hline & & \multicolumn{5}{|c|}{ Ocena średnia } & \multirow[b]{3}{*}{4.1} \\
\hline & & \begin{tabular}{|c} 
Zdecydowanie \\
Nie
\end{tabular} & $\mathrm{Nie}$ & \begin{tabular}{|c|} 
W \\
niewielkim \\
stopniu
\end{tabular} & TAK & \begin{tabular}{|c|} 
Zdecydowanie \\
TAK
\end{tabular} & \\
\hline & & \multicolumn{5}{|c|}{ I } & \\
\hline \multicolumn{8}{|l|}{2.} \\
\hline \multicolumn{8}{|c|}{ Czy było to działanie pozytywne? } \\
\hline Odpowiedż & \multicolumn{4}{|l|}{ Średnia } & \multicolumn{3}{|c|}{ Sumarycznie } \\
\hline Tak & \multicolumn{6}{|c|}{$100 \%$} & 29 \\
\hline $\mathrm{Nie}$ & & 0 \\
\hline Sumarycznie & \multicolumn{6}{|c|}{$100 \%$} & $29 / 29$ \\
\hline \multicolumn{8}{|l|}{3.} \\
\hline \multicolumn{8}{|c|}{ Czy wprowadzenie elementów zdalnego nauczania było pomocne w lepszym zrozumieniu nauczanych treści z tego przedmiotu? } \\
\hline & & \multicolumn{5}{|c|}{ Ocena średnia } & \\
\hline & & \begin{tabular}{|c|}
$\begin{array}{c}\text { Zdecydowanie } \\
\text { Nie }\end{array}$ \\
\end{tabular} & $\mathrm{Nie}$ & \begin{tabular}{|c|}
$W$ \\
niewielkim \\
stopniu
\end{tabular} & TAK & \begin{tabular}{|c|} 
Zdecydowanie \\
TAK
\end{tabular} & \\
\hline & & \multicolumn{6}{|r|}{4.1} \\
\hline
\end{tabular}

Figure 3. Examples of students' responses to survey questions 1-3

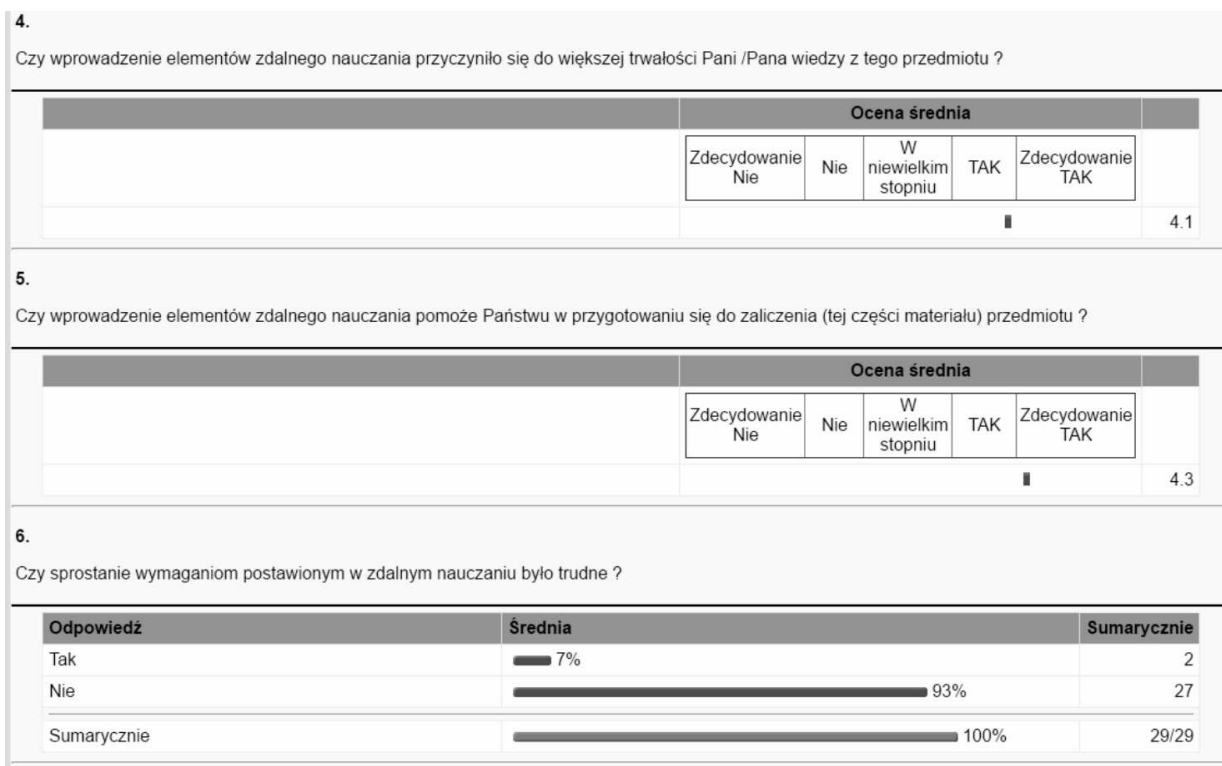

Figure 4. Examples of students' responses to survey questions 4-6

any time, a more comfortable learning environment, saving time, permanent access to materials, access to educational materials, a better understanding of the issues and possibility of checking knowledge. Examples of answers are presented in Figure 6. 
12.

Czy gdyby była możliwość w przyszłości korzystania z takiej formy zajęć prowadzonych zdalnie (on-line) to korzystaliby Państwo z tej formy edukacji ?

\begin{tabular}{|c|c|c|c|c|c|c|c|c|}
\hline Odpowiedź & \multicolumn{6}{|l|}{ Średnia } & \multicolumn{2}{|c|}{ Sumarycznie } \\
\hline Tak & \multicolumn{6}{|c|}{$100 \%$} & \multicolumn{2}{|r|}{29} \\
\hline $\mathrm{Nie}$ & & & & & & & \multicolumn{2}{|r|}{0} \\
\hline Sumarycznie & \multicolumn{6}{|c|}{$100 \%$} & \multicolumn{2}{|r|}{$29 / 29$} \\
\hline \multicolumn{9}{|l|}{13.} \\
\hline \multicolumn{9}{|c|}{ Jak sądzą Państwo - jaki jest wpływ e-learningu na wizerunek Państwa uczelni ? } \\
\hline & & \multicolumn{6}{|c|}{ Ocena średnia } & \\
\hline & & $\begin{array}{c}\text { Zdecydowanie } \\
\text { negatywny }\end{array}$ & Negatywny & \begin{tabular}{|c|} 
Nie \\
wpływa \\
(nie \\
wiem)
\end{tabular} & Pozytywny & \multicolumn{2}{|c|}{$\begin{array}{c}\text { Zdecydowanie } \\
\text { pozytywny }\end{array}$} & \\
\hline & & \multicolumn{6}{|c|}{ I } & 4.7 \\
\hline
\end{tabular}

Figure 5. Examples of students' responses to survey questions 12-13

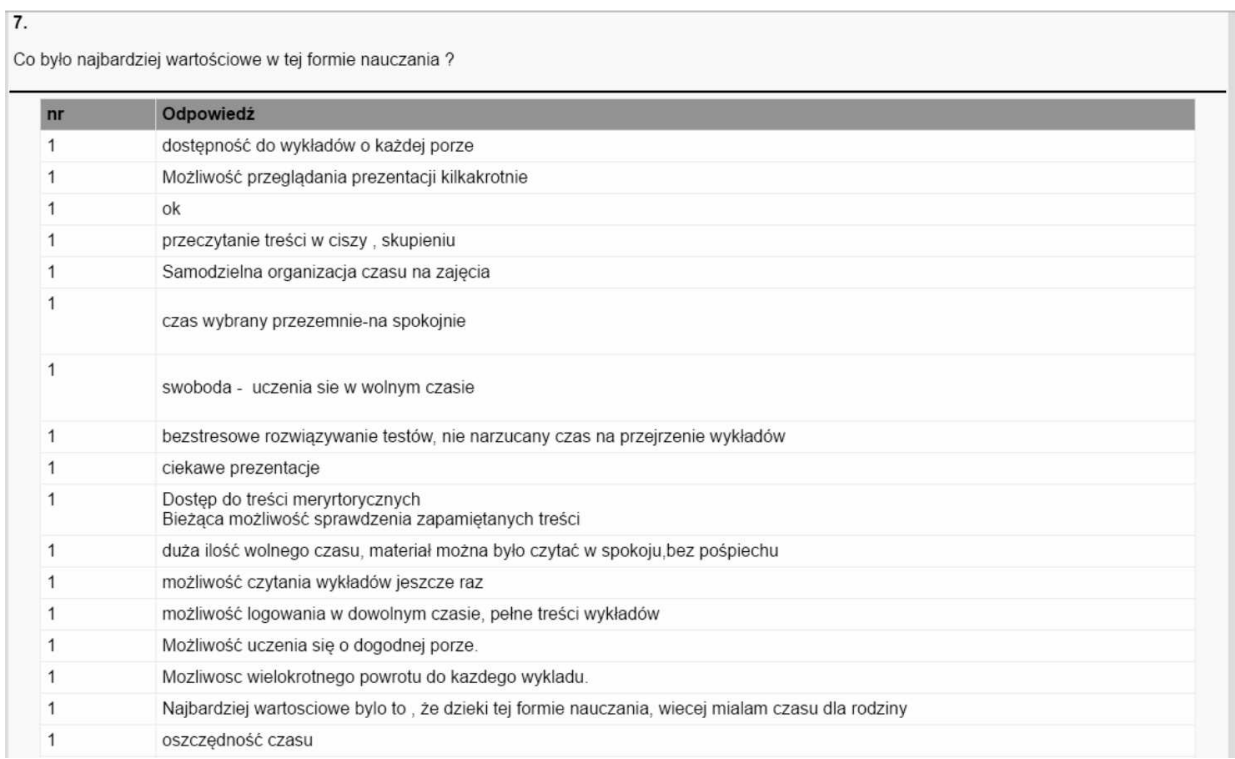

Figure 6. Examples of students' responses to the question: "What was the most valuable in this form of education?"

Dominant replies to the question: "What was the most burdensome in this form of learning?" were: "courses did not cause any inconvenience", "omission of the terms of access to quizzes", "occasional technical problems with access to the system" (Figure 7). 
Co było najbardziej uciązliwe $w$ tej formie nauczania ?

\begin{tabular}{|c|c|}
\hline $\mathrm{nr}$ & Odpowiedż \\
\hline 1 & brak systematyczności z mojej strony \\
\hline 3 & nic \\
\hline 1 & - niektóre slajdy były za bardzo przeładowane tekstem \\
\hline 1 & Kursy nie sprawialy dla mnie zadnych uciazliwosci,jasny przekaz i ciekawa forma. \\
\hline 1 & ograniczenia czasowe \\
\hline 1 & Pilnowanie terminow do kiedy nalezy przeczytac wyklady i rozwiazac tasty. \\
\hline 1 & brak systematycznosci \\
\hline 1 & Czasami nie dzialały strony, chodzi mi o okulistyke rozwiazywane testy nie zapisywały sie i nie pokazywało ocen \\
\hline 1 & czasami nie mozna bylo zalogowac sie na tej stronce internetowej \\
\hline 1 & dlugie soedzenie przed kimputerem \\
\hline 1 & jesli sie nie zdążyło zrobić test do konkretnego terminu to potem było to tym bardziej nie mozliwe \\
\hline 1 & Jestem na bakier ze znajomoscia obslugi komputera. \\
\hline 1 & Nic nie było uciążliwe. \\
\hline 1 & Nic \\
\hline 1 & Nie miałam uciązliwości. \\
\hline
\end{tabular}

Figure 7. Examples of students' responses to the question: "What was the most burdensome in this form of learning?"

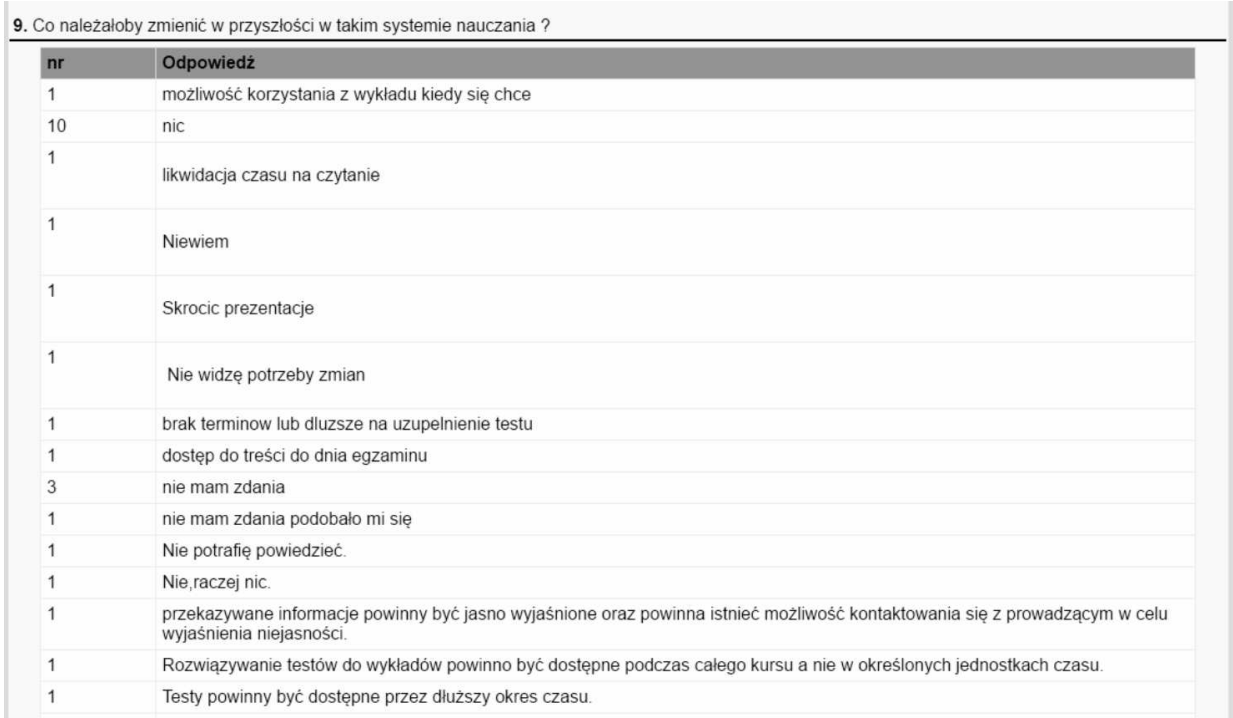

Figure 8. Examples of students' responses to the question: "What should be changed in such a system of learning in the future?"

Responses to the question "What should be changed in such a system of learning in the future?" were: "the system does not need to be changed", "expand e-learning for other subjects", "extend time to respond during tests", "enter more multimedia pieces" (Figure 8). 
The final results of the exam after completing the course "Problems of multiculturalism in medicine" are shown in Table 3. The final results of the exams for the courses "Selected issues of visual rehabilitation" and "Ophthalmology and ophthalmological nursing" are presented in Tables 4 and 5 . The differences in the final results (grades) obtained in each of the subjects were not statistically significant $(\mathrm{p}>0.05)$.

Table 3. Final results (\%) of the subject "Problems of multiculturalism in medicine"

\begin{tabular}{|c|c|c|c|c|c|c|c|c|c|}
\hline Group & $\mathrm{n}$ & Mean & $\mathrm{SD}$ & Min & $\mathrm{Q}_{1}$ & $\mathrm{Me}$ & $\mathrm{Q}_{3}$ & Max & $\mathrm{p}$ value \\
\hline e-learning & 29 & $82 \%$ & $14 \%$ & $53 \%$ & $67 \%$ & $80 \%$ & $96 \%$ & $100 \%$ & \multirow{2}{*}{0.12} \\
\hline traditional & 24 & $83 \%$ & $12 \%$ & $58 \%$ & $77 \%$ & $85 \%$ & $93 \%$ & $100 \%$ & \\
\hline
\end{tabular}

Table 4. Final results (\%) of the subject "Selected issues of visual rehabilitation"

\begin{tabular}{|c|c|c|c|c|c|c|c|c|c|}
\hline Group & $\mathrm{n}$ & Mean & $\mathrm{SD}$ & Min & $\mathrm{Q}_{1}$ & $\mathrm{Me}$ & $\mathrm{Q}_{3}$ & Max & $\mathrm{p}$ value \\
\hline e-learning & 19 & $79 \%$ & $9 \%$ & $58 \%$ & $73 \%$ & $82 \%$ & $85 \%$ & $89 \%$ & \multirow{2}{*}{0.27} \\
\hline traditional & 34 & $76 \%$ & $12 \%$ & $46 \%$ & $69 \%$ & $81 \%$ & $84 \%$ & $88 \%$ & \\
\hline
\end{tabular}

Table 5. Final results (\%) of the subject "Ophthalmology and ophthalmological nursing"

\begin{tabular}{|c|c|c|c|c|c|c|c|c|c|}
\hline Group & $\mathrm{n}$ & Mean & $\mathrm{SD}$ & Min & $\mathrm{Q}_{1}$ & $\mathrm{Me}$ & $\mathrm{Q}_{3}$ & Max & $\mathrm{p}$ value \\
\hline e-learning & 24 & $85 \%$ & $13 \%$ & $54 \%$ & $79 \%$ & $85 \%$ & $97 \%$ & $99 \%$ & \multirow{2}{*}{0.32} \\
\hline traditional & 29 & $83 \%$ & $14 \%$ & $55 \%$ & $78 \%$ & $85 \%$ & $96 \%$ & $99 \%$ & \\
\hline
\end{tabular}

The obtained results allow us to conclude that distance education can be a very good way to supplement traditional teaching in medical training, and in some forms of activities, such as lectures or seminars, can successfully replace traditional methods. High average final results of the subjects and the positive feedback from students indicate a robust level of preparation of teaching materials and good organization of classes. Popularity of distance learning may be due to continuous access to knowledge contained in the online course and the attractive form of the content. Our study included groups of nursing students, studying in the traditional and distance manner. The comparison of those two methods of education confirmed the 
Wiesław Pótjanowicz et al.

assumption that the use of e-learning methods did not worsen professional knowledge, students' satisfaction or the effectiveness of teaching students as compared to traditional teaching.

\section{Conclusions}

The results obtained for part-time master's degree medical students allow us to conclude that the e-learning method is as effective as traditional methods of teaching, at least in the subjects: "The problems of multiculturalism in the medicine", "Selected issues of visual rehabilitation" and "Ophthalmology and ophthalmological nursing". The introduction of distance learning was responsible for changing the way students learned, as declared by $85 \%$ of the surveyed students. Eighty-eight percent of students rated distance learning as helpful in better understanding the learning content and $76 \%$ of students declared that e-learning contributed to broadening their knowledge. Ninety-four percent of students declared that distance learning was helpful in preparing them to complete courses. Eighty-eight percent of students had no difficulty in meeting set distance learning standards. The average results obtained from the final exams were comparable in both groups (e-learning and traditional) for each subject. Ninety-six percent of students stated that they could possibly benefit from this form of education in the future and $91 \%$ of students rated the impact of e-learning on the image of the university positively. Didactic content, developed in multimedia form and placed on the e-learning platform, was available to students throughout the academic year and allowed for more flexible learning and preparation for the final exams, while at the same time helping students to consolidate and assimilate knowledge.

\section{R E F E R E N C E S}

Allan, B. (2007). Time to learn? E-learners' experiences of time in virtual learning communities. Management Learning, 38, 557-572.

Bramley, P. (2011). Ocena efektywności szkoleń. (ang. Evaluating training effectiveness) Warsaw: Wolters Kluwer Poland.

Clarke, A. (2007). E-learning nauka na odległość. Warszawa: WKE.

Hyla, M. (2012). Guide to e-learning. Warsawa: Wolters Kluwer Poland.

Kołodziejczak, B., Roszak, M., Kowalewski, W., Ren-Kurc, A., \& Bręborowicz, A. (2014). Participants academic distance education - Case study. Technics Technologies Education Management, 10(2), 242-249. 
Meger, Z. (2010). Tendencje współczesnej edukacji - od a-Learning do z-Learning. In L. Banachowski, (Ed.), Postepy e-edukacji (pp. 16-25). Warszawa: Wydawnictwo PJWSTK.

Piskurich, G. M. (2003). The AMA Handbook of E-Learning, Effective Design, Implementation, and Technology Solutions. New York: AMACOM.

Półjanowicz, W. (2014). Efektywność zdalnej edukacji w aspekcie nauczania przedmiotów medycznych. In M. Dąbrowski, \& M. Zając (Eds.), E-edukacja w praktyce - wyzwania i bariery (pp. 89-104). Warszawa: Fundacja Promocji i Akredytacji Kierunków Ekonomicznych.

Półjanowicz, W., Latosiewicz, R., Kulesza-Brończyk, B., Piekut, K., Kalisz, A., Piechocka, D. I., \& Terlikowski, S. J. (2010). Comparative analysis of elearning and traditional teaching methods in the field of nursing in the Medical University of Bialystok. The chosen aspects of woman and family's health. Vol. 2, 94-104, Bydgoszcz.

Półjanowicz, W., Latosiewicz, M., \& Terlikowski, J. (2012). The results of teaching of subject "Obstetrics, gynecology and gynecological and obstetric nursing" with the use of e-learning platform at the Faculty of Health Sciences, Medical University of Bialystok. Studies in Logic, Grammar and Rhetoric. Logical, Statistical and Computer Methods in Medicine, 29(42), 181-192.

Półjanowicz, W., Mrugacz, G., Szumiński, M., Latosiewicz, R., BakunowiczŁazarczyk, A., Bryl, A., \& Mrugacz, M. (2013). Assessment of the Effectiveness of Medical Education on the Moodle e-Learning Platform. Studies in Logic, Grammar and Rhetoric. Logical, Statistical and Computer Methods in Medicine, 35(48), 203-214. DOI: 10.2478/slgr-2013-0037.

Półjanowicz, W., Roszak, M., Kołodziejczak, B., \& Bręborowicz, A. (2014). An analysis of the effectiveness and quality of e-learning in medical education. In E. Smyrnova-Trybulska (Ed.), E-learning and Intercultural Competences Development in Different Countries (pp. 177-196). Katowice-Cieszyn: Studio Noa.

Rice, W. H. (2010). Tworzenie serwisów e-learningowych z Moodle 1.9 (pp. 155272). Gliwice: Helion.

Roszak, M., Kołodziejczak, B., Kowalewski, W., \& Ren-Kurc, A. (2013). Standard Question and Test Interoperability (QTI) - ewaluacja wiedzy studenta. Ementor, 2(49), 35-40.

Roszak, M., Kołodziejczak, B., Kowalewski, W., \& Ren-Kurc, A. (in press). Implementation of e-learning portal for academic education and lifelong learning. International Journal of Continuing Engineering Education and Life-Long Learning.

Smith, G. G., Heindel, A. J., \& Torres-Ayala, A. T. (2008). E-learning commodity or community: Disciplinary differences between online courses. The Internet and Higher Education, 11(1), 152-159. 
Wiestaw Pótjanowicz et al.

Smyrnova-Trybulska, E. (2009). About some basic aspects of distance learning. In E. Smyrnova-Trybulska (Ed.), Theoretical and practical aspects of distance learning, Collection of Scholarly Papers (pp. 13-35). Visegrad Fund: Cieszyn.

Wu, W. C., \& Hwang, L. Y. (2010). The effectiveness of e-learning for blended courses in colleges: a multi-level empirical study. International Journal of Electronic Business Management, 8(4), 312-322. 